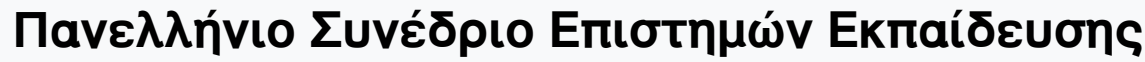

Tó $\mu .1$, Ap. 1 (2020)

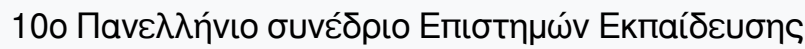

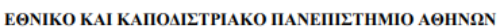

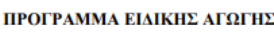

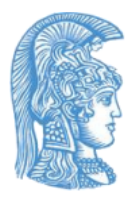

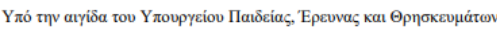

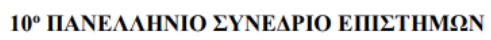

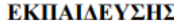

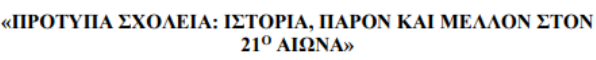

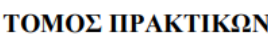

19-21 Iovvíov 2020

ISSN: 2529-1157
The role of audiovisual resources in active learning methodologies

Vasiliki Anagnostopoulou, Verónica Izquierdo Becerro

doi: $\underline{10.12681 / \text { edusc. } 3363}$ 


\title{
The role of audiovisual resources in active learning methodologies
}

\author{
Anagnostopoulou Vasiliki \\ Primary School Teacher, Universidad de Salamanca \\ vasilikianagn@usal.es \\ Izquierdo Becerro Verónica \\ Primary School Teacher, Universidad de Salamanca \\ veronicaizquierdo@usal.es
}

\section{Пврі́ $\eta \psi \eta$}

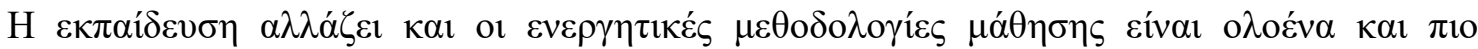

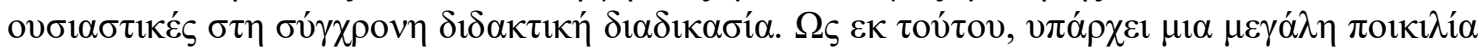

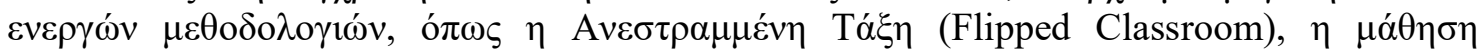

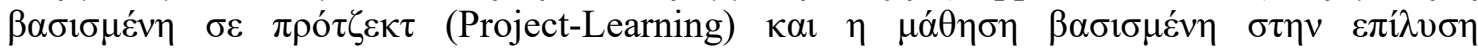

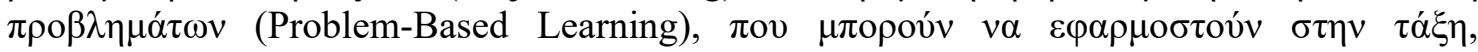

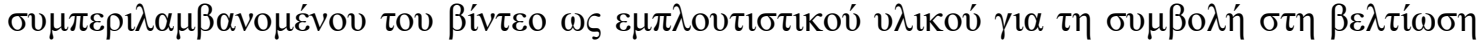

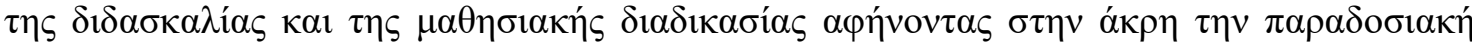

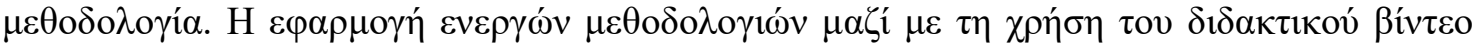

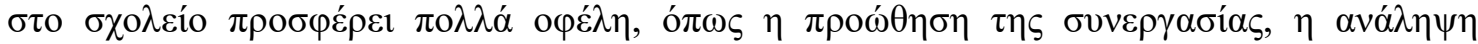

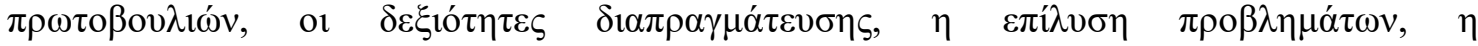

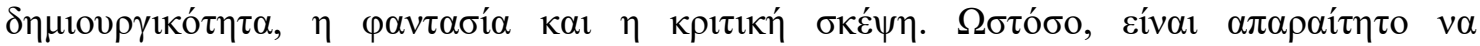

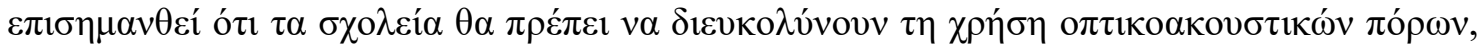

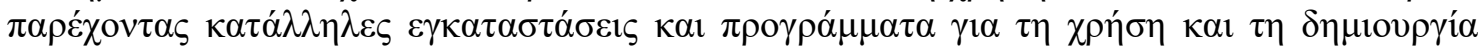

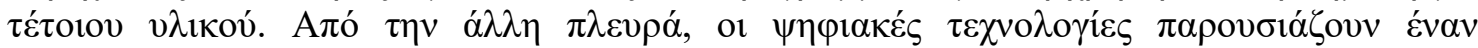

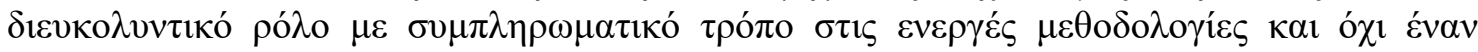

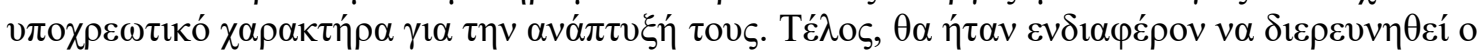

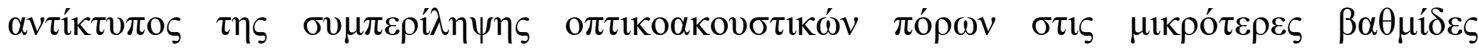

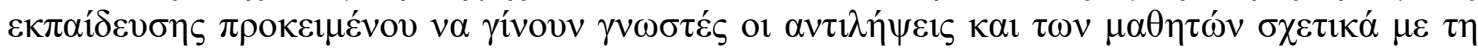

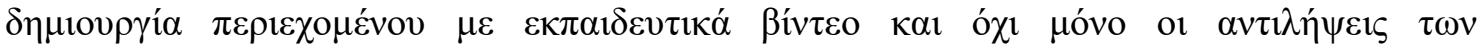
$\varepsilon \kappa \pi \alpha \iota \delta \varepsilon v \tau \iota \kappa \dot{v}$.

\begin{abstract}
Education is changing and active learning methodologies are increasingly essential in the modern teaching process. Therefore, there are a wide variety of active methodologies, such as
\end{abstract}


the Flipped Classroom, Project-Based Learning and Problem-Based Learning, which can be implemented in the classroom, including video as an enriching resource to contribute to the improvement of the teaching and learning process leaving aside the traditional methodology. The implementation of active methodologies together with the use of didactic video in the school offers several benefits such as the promotion of cooperation and collaboration, initiative taking, negotiation skills, problem solving, creativity and imagination and critical thinking. However, it is necessary to point out that schools should facilitate the use of audiovisual resources, providing adequate facilities and programs for the use and creation of such materials. On the other hand, digital technologies present a facilitating role in a complementary way to active methodologies and not an obligatory role for their development. Finally, it would be interesting to investigate the impact of the inclusion of audiovisual resources at lower levels such as Primary Education, in order to know the students' perceptions about the creation of content with educational videos and not only the teachers' perceptions.

Keywords: Audiovisual Resources, Video, Image, Active Methodologies.

\section{Introduction}

Changes in society affect education, which continues to advance and evolve, adapting its objectives and resources. In recent years, one of the main objectives has been to get students to assume a more significant role in the whole educational process and thus become active agents in shaping their learning. Consequently, different active teaching methodologies have been introduced, such as Project-Based Learning, Problem-Based Learning and Flipped Classroom or Inverted Classroom (Arruabarrena et al., 2019). According to Ruíz et al. (2020), these tools prove to be effective in generating meaningful learning and forming critical and creative individuals who are prepared to face both current and future challenges in order to be able to work in teams, communicate, debate and evaluate.

Currently, the use of images and video is a powerful didactic resource in the teaching-learning process. Videos in education are often used to teach students specified content according to the didactic objectives, or they can be elaborated by teachers or students, as a means of presenting what they have learned, their ideas or feelings (Greene, 2014). Audiovisual resources are often being incorporated as part of active methodologies in different ways, generating a positive impact on student learning.

This paper briefly analyses the role of audiovisual resources in active methodologies. Specifically, the most relevant ideas found in the scientific literature are extracted, exactly those that are considered most important and powerful. Next, an interpretation-valuation of the different authors is presented, together with a series of questions that have arisen when analysing the chosen topic. Finally, some general conclusions about this report are included.

\section{The role of audiovisual resources in active methodologies}


Education is changing and active learning methodologies are increasingly essential in the modern teaching process. Through these methodologies, teaching is brought closer to real life, involving students in the learning process. In addition, with the proliferation of Web 2.0 technologies, digital content can be reused and created in forms such as wikis, blogs, reports, videos and images. These resources can be generated by teachers themselves or even by students as part of their learning process (Arruabarrena et al., 2019). The following active methodologies are presented below: Inverted Classroom, Project-based Learning, Problem-based Learning, which are currently being increasingly implemented in classrooms and incorporate audiovisual resources as part of them.

\subsection{The use of video in the Flipped Classroom}

The Flipped Classroom (FC) method is based on the idea of inverting traditional teaching, replacing a teacher-centred approach with one in which activities that used to take place outside the classroom are now carried out inside it. This type of methodology is developed in two phases and its procedure is as follows: before class, students access different materials, such as texts, videos, blogs, repositories, and then perform various activities in the classroom, such as quizzes, problem solving, debates, concept analysis, and so on (Arruabarrena et al., 2019). This type of learning is a methodology that feels supported by technology being video the most used resource for it. In addition, it produces a change not only in the role of the teacher but also in the realization of teaching materials, which, can serve for the preparation of audiovisual resources and their implementation in a face-to-face manner (Palazón-Herrera, 2018).

In a flipped classroom, the teacher is responsible for preparing the material. Therefore, he/she has to select and edit the materials to get them successfully adapted in the classroom. Many online platforms and video editing tools can be found (Moreno et al., 2020). Likewise, there are several open access materials that can also be used, such as, for example, YouTube, Tiching, Khan Academy, Ted Talks, MIT Open Courseware (Arruabarrena et al., 2019), but just because they are used does not mean that this is a flipped classroom. When selecting a video, the teacher must evaluate aspects that meet the requirements of a flipped classroom. These are curricular, pedagogical, expressive, technical, instructional and aesthetic. Also, the possible problem-solving scenarios, the existence of different register representations, the clarity and precision of the definitions and how the premises and procedures are structured have to be considered (Moreno et al., 2020).

According to Akçayır et al. (2018), this methodology has its advantages and challenges. It increases students' satisfaction, improves learning, enhances students' problem-solving abilities, and develops critical thinking skills. On the other hand, alternative interaction with teachers, as well as individualized learning, makes students more interested and better prepared for class. The individualized attention that accompanies didactic videos also helps people with learning difficulties to obtain better results (Moreno et al., 2020).

According to the contributions of Palazón-Herrera (2018) made in her study based on instrumental practice, she states that students value the use of video in FC methodology as a motivating resource that increases confidence for the work done in subsequent classes, as well as their performance both at home and in class, in which, teachers are allowed more time 
to attend to their students and resolve doubts. Furthermore, in this study it can be observed that all participants agreed that the use of video is the most appropriate resource for instrumental practice, leaving aside the notes and the textbook.

However, to ensure the effectiveness of the "Flipped Classroom", it is more important to focus on the selection of active learning strategies to be used in class than on the development of online videos or other materials outside the classroom. It is necessary to consider which activities will be most conducive to learning and, analyse whether such tasks are best done before, during or after the face-to-face session, as well as the types of interactions with the material and among learners that are desirable (Arruabarrena et al., 2019).

\subsection{The use of video in Project-Based Learning}

Project-oriented learning environments are very focused on the students' learning process and their particular needs, which requires teachers to act as supervisors and advisors (Torío, 2019). The main characteristic of Project-Based Learning tries to guarantee a real learning context to students, explaining to them in a direct way the teaching and learning process. Each student is responsible for carrying out a series of decisions to achieve the resolution of a given task with a certain degree of complexity (Abella et al., 2020).

Generally speaking, students are the protagonists of deciding, planning and elaborating the projects they want to put into practice. This type of learning generates autonomy and responsibility in the students during the elaboration of the projects and its progression should occur both quantitatively and qualitatively. In addition to increasing self-confidence and motivation, since each student sets a challenge followed by a common thread (Abella et al., 2020). In addition, project-based learning is an educational model, which aims to bring academic teaching closer to social and work contexts in order to develop a student-centred instructional approach. This didactic methodology aims to relate practice with theory by encouraging teamwork from various interdisciplinary perspectives. In short, students teach and learn at the same time through experiences that are carried out in a cooperative manner in which all members collaborate and do not compete (Simó et al., 2016).

On the other hand, this alternative approach has a positive impact on students' motivation, satisfaction and performance. In particular, Torío (2019) conducted an active research using a video-based approach combined with project-oriented learning. Students had seven days to review videos through the Vimeo platform, where they could watch them at their own pace. Each video session corresponded to a weekly homework assignment. It was found that this environment can be a potential tool to facilitate the transition from knowledge dissemination to knowledge appropriation. In addition, the results showed a high level of student satisfaction and performance during the course. Students' self-perceived competencies during the course far exceed those possible from a traditional teaching approach.

Also, the students themselves are able to create content as part of the projects. Students have started to become video producers in the academic context and especially in the field of humanities and education (Greene, 2014). Video production allows students to express themselves in a way that makes them feel more comfortable, increasing their motivation to stimulate more imaginative creations (Droumeva \& Murphy, 2016). In addition, students express high levels of satisfaction, and even if not all students are able to generate valuable 
new content, many are able to appreciate it when their peers do so. However, video production requires practice and experience that not everyone possesses (Arruabarrena et al., 2019). Therefore, the role of teachers and their knowledge in technological tools is very important.

The use of video in this type of learning can be carried out for multiple purposes. It can serve as a research resource with the aim that students learn to search and select various videos for the acquisition of verbal channels and visual channels in which children observe and listen and, subsequently, reproduce in an enriching way. On the other hand, the use of video as a competency task is also considered a good tool, because students learn to create videos with diverse content and improve their oral communication and expressive skills. In short, it is a resource for detecting skills and strengths in order to learn how to improve them and generalize habits of self-assessment and co-assessment (Marín, 2014).

\subsection{The use of video in Problem-Based Learning}

Problem-based learning (PBL) is a type of teaching that reflects active learning. It is a learner-centred pedagogy, in which the learner learns about a subject by trying to find a solution to an open-ended problem (Phungsuk et al., 2017). In addition, it is considered as a pedagogical - methodological and multididactic approach, due to the fact that it allows students to build their own knowledge and feel as protagonists of their own learning (Hincapié et al., 2016).

According to Piñero (2017), in the 1980s, this type of learning marked the field of education and teaching, since it was a turning point, serving as a reference to achieve and implement collaborative work. PBL is an active way for students to learn basic problem-solving skills in small self-directed groups to define and carry out specific tasks, whether real-life or study tasks. This "learning by doing" technique prepares students for their future careers (Phungsuk et al., 2017).

Various researches put forward PBL as a methodology that is based on constant and effective work from the point of view of a number of disciplines and areas, with emphasis on the area of Natural Sciences. On the other hand, it counteracts all kinds of problems that can be witnessed in the traditional methodology, giving rise to a pedagogical option that favours meaningful student learning (Aguado \& Campo, 2017).

The use of video as a resource in this type of learning, provides a number of advantages. There are several forms of media that provide knowledge, such as videos to teach the different steps of a work. The learning model focuses on the problem-solving process, which empowers learners to solve problems through knowledge inquiry processes. Therefore, it prepares learners to engage in self-study, which becomes continuous learning (Phungsuk et al., 2017). In addition, the increased involvement on the part of the learner results in more meaningful learning. Likewise, it favours reasoning by getting students to expand their memory due to the visual information they receive when watching such resources. Other fundamental aspects offered by video correspond to the development of observation, retention and experience carried out in healthcare practices (Salvat et al., 2010). 
Learning media in the form of videos can take place on a scientific basis through the problem-based learning model. Simanjuntak et al. (2019) found that videos can improve student learning outcomes and that the influence of their use is greater compared to teaching materials used on a daily basis. A teacher who uses media and learning models appropriately can adjust core competencies according to students' conditions. This will affect students' learning outcomes both from cognitive, affective and psychomotor points of view. However, Simanjuntak et al. (2019) emphasized that although the use of science-based videos as part of problem-based learning can improve students' learning outcomes, it should not be the main medium used in the learning process.

\section{Discussion and Implications for Practice}

Active methodologies correspond to alternative methodologies to traditional teaching, which allow students to learn in an active way. The methodologies whose role seems very promising in recent years and which were subsequently analysed are: Flipped Classroom, Project-based Learning and Problem-based Learning. The role of audiovisual resources, and technologies in general, is a facilitator in the use of active methodologies in the classroom, because they allow teachers and students to do many more things in a ubiquitous and collaborative way. Their use is significant, because they have consolidated these methodologies as the most successful way for the development of authentic learning. Each one makes use of audiovisual resources in a different way, including student participation in the teaching-learning process.

On the other hand, referring to the audiovisual media, specifically, the didactic video, it is necessary to point out that they offer a great training for both students and teachers. This resource acts as a facilitating channel both in the delivery of content and in the increase of motivation in the acquisition of active learning. It also enhances the creativity of teachers and their way of transmitting and communicating various disciplinary topics (Troncoso et al., 2019).

The model of active methodologies is ideal for training students' capacity for critical thinking, creative thinking, problem solving, cooperation, collaboration and communication, skills that are important for students in the 21st century (Bakri et al., 2018). According to several studies, students who have followed this type of learning have acquired better problem-solving skills, being more self-reliant and showing greater commitment to their learning (Abella et al., 2020). These are powerful tools aimed at the development of student competencies, which are necessary for adequate student learning.

However, it is necessary to point out that both these methodologies and the use of video must be carried out in an appropriate manner in schools in order to achieve the proposed objectives. At the same time, schools must facilitate the use of audiovisual resources, providing adequate facilities and programs for the use and creation of such materials. In any case, digital technologies present a facilitating role in a complementary way to active methodologies and not an obligatory or absolutely necessary role for their development.

After analysing the bibliographical references, it can be pointed out that there is a great variety of articles focused on the three active methodologies mentioned above. However, it is true that, of the three active methodologies mentioned, less information has been found on the 
use of videos in problem-based learning, most of them being focused on higher education, i.e., university. Therefore, we consider that it would be interesting to carry out research of this type focused on these methodologies in Primary Education, since enriching results could be obtained.

On the other hand, it is important to point out that more research on the use of audiovisuals in active learning methodologies would be desirable. Specifically, in different subjects and different levels of education. All this is essential if the possible benefits and challenges regarding the use of audiovisual resources appear in more than one curricular subject and not only in the highest levels of education, such as university education.

Finally, it would be enriching to investigate the impact of the inclusion of audiovisual resources at lower levels such as Primary Education, in order to know the students' perceptions about the creation of educational videos and not only the teachers' perceptions. We consider that this aspect could be interesting, since the current students of the society in which we live, belong to the generation familiar with technologies, resulting in that in several occasions they know how to handle audiovisual resources more easily than teachers.

\section{Conclusions}

This paper briefly analyses the role of image and video in active learning methodologies. After carrying out a bibliographic review on the chosen topic, a series of conclusions have been reached, taking as a reference several contributions from various authors, which are subsequently pointed out.

Firstly, technological advances have allowed the visualization of videos and their production at any time and place. The generation of video content seems to help increase student participation in the learning process (Arruabarrena et al., 2019). Likewise, the wide variety of active methodologies, such as the Inverted Classroom, Project-Based Learning and Problem-Based Learning, can be implemented in the classroom including video as an enriching resource for the improvement of the teaching and learning process of students.

Specifically, active methodologies together with the use of didactic video in the school offer various benefits such as the development of a series of competencies and skills necessary in students, as well as the promotion of cooperation and collaboration; initiative taking; negotiation skills; problem solving, creativity and imagination and critical thinking (Abella et al., 2020; Bakri et al., 2018). In addition, these methodologies offer different dynamics for learning and development of didactic content, enhancing an alternative teaching, away from the methodology that has been used for years.

Because the image and audiovisual resources have an important role in education, it is necessary the adequate training of teachers in the new methodologies adapted to the context and social demand. Therefore, it is essential that teachers attend training courses where they acquire the knowledge and digital skills necessary to properly manage audiovisual resources, as is the case of educational video (Agüero, 2016).

However, the integration of the technological, pedagogical and teaching components of the subject seem to be more important for the development of quality educational videos than the technological component alone. Moreno et al. (2020) evaluated the impact of teachers' 
digital competence on the quality of videos developed for a flipped classroom, in which, no correlation was observed. In any case, teacher training should incorporate elements that emphasize the application of technology to the pedagogical process of subject instruction (Droumeva \& Murphy, 2016).

To conclude, it is important that more research be conducted on the audiovisual use in active learning methodologies. It would be interesting to investigate which are the most powerful applications aimed at children for the use o creation of videos. Also, future research could focus on the role of audiovisual resources related to active methodologies aimed at the lower stages of the educational field.

\section{References}

Abella, V., Ausín, V., Delgado, V., \& Casado, R. (2020). Aprendizaje basado en proyectos y estrategias de evaluación formativas: Percepción de los estudiantes universitarios. Revista Iberoamericana de Evaluación Educativa, 13(1), 93-110. https://doi.org/10.15366/riee2020.13.1.004

Aguado, A., \& Campo, A. (2017). Desarrollo de competencias científicas en biología con la metodología del aprendizaje basado en problemas en estudiantes de noveno grado.

Escritos sobre la biología y su enseñanza, 11(20), 67-78. https://revistas.pedagogica.edu.co/index.php/bio-grafia/article/view/8594/6511

Agüero, M. (2016). Recursos tecnológicos utilizados en la didáctica docente de Educación Primaria y básica. Revista científica en el área de estudios virtuales y tecnología educativa, 3(9), 126-140. http://www.uft.edu.ve/campusvirtual/revistacampusvirtual\%20Edi.\%20IX\%20(9)/articulo $\% 208 . p d f$

Akçayır, G., \& Akçayır, M. (2018). The flipped classroom: A review of its advantages and challenges. Computers \& Education, 126, 334-345. https://doi.org/10.1016/j.compedu.2018.07.021

Arruabarrena, R., Sánchez, A., Blanco, J. M., Vadillo, J. A., \& Usandizaga, I. (2019). Integration of good practices of active methodologies with the reuse of student-generated content. International Journal of Educational Technology in Higher Education, 16(10), 1-20. https://doi.org/10.1186/s41239-019-0140-7

Bakri, F., Sunaryo, S., Irawan, V. F., \& Muliyati, D. (2018). E-Learning Model for Problem Based Learning on Heat and Thermodynamic Topics in High School. Jurnal Penelitian \& Pengembangan Pendidikan Fisika, 4(2), 101-112. https://doi.org/10.21009/1.04207

Droumeva, M., \& Murphy, D. (2016). A sound pedagogy: Active learning through media production. EDULEARN16 Proceedings, 3974-3982.

https://doi.org/10.21125/edulearn.2016.1949 
Greene, H. (2014). Learning through student created, content videos. International Journal of Arts \& Sciences, 7(2), 469-478.

Hincapié, D. A., Ramos, A., \& Chrino-Barceló, V. (2016). Aprendizaje Basado en Problemas como estrategia de Aprendizaje Activo y su incidencia en el rendimiento académico y Pensamiento Crítico de estudiantes de Medicina. Revista Complutense de Educación, 29(3), 665-681. https://doi.org/10.5209/RCED.53581

Marín, V. (2014). Aprendizaje basado en Proyectos en y uso del vídeo. Experiencias de trabajo en el aula de Ciencias Sociales. In J. Hernández \& E. Martín (Eds.), Pedagogía Audiovisual: Monográfico de experiencias docentes multimedia (pp. 191-202). Servicio de Publicaciones, Universidad Rey Juan Carlos.

Moreno, D., Palacios, A., Barreras, Á., \& Pascual, V. (2020). An Assessment of the Impact of Teachers' Digital Competence on the Quality of Videos developed for the Flipped Math Classroom. Mathematics, 8(2), 1-16. https://doi.org/10.3390/math8020148

Palazón-Herrera, J. (2018). Audiovisuales para la práctica instrumental en un escenario flipped classroom. Revista electrónica de LEEME, (42), 54-69. https://doi.org/10.7203/LEEME.42.13055

Phungsuk, R., Viriyavejakul, C., \& Ratanaolarn, T. (2017). Development of a problem-based learning model via a virtual learning environment. Kasetsart Journal of Social Sciences, 38(3), 297-306. https://doi.org/10.1016/j.kjss.2017.01.001

Piñero, J. C. (2017). Un paso más en el aprendizaje basado en problemas, aprendizaje mixto. Actas de La II Jornadas de Innovación Docente Universitaria UCA, 62-67. https://jornadas-innovaciondocente.uca.es/edicion-anterior-2017/libro-de-actas-2017/

Ruiz, F., Zapatera, A., \& Montes, N. (2020). "Sustainable City": A Steam Project Using Robotics to Bring the City of the Future to Primary Education Students. Sustainability, 12(22), 1-21. https://doi.org/10.3390/su12229696

Salvat, I., Gonzalez, A. P., Monterde, S., Montull, S., \& Miralle, I. (2010). Utilización del video para presentar los casos en el aprendizaje basado en problemas. Revista de Medios y Educación, 37, 171-183. https://www.redalyc.org/pdf/368/36815118014.pdf

Simanjuntak, L. Y. A., Perangin-Angin, R. B., \& Saragi, D. (2019). Development of Scientific Based Learning Video Media Using Problem Based Learning (PBL) Model to Improve Student Learning Outcomes in 4Th Grade Students of Elementary School Parmaksian, Kab. Sambair Toba. Budapest International Research and Critics in Linguistics and Education (BirLE) Journal, 2(4), 297-304. https://doi.org/10.33258/birle.v2i4.517 
Simó, A., Ferreira, S., \& Ortuño, P. (2016). Workshops interdisciplinares: Implementación de metodologías de aprendizaje basado en proyectos y cooperativo. Opción, 32(10), 752-772. https://www.redalyc.org/pdf/310/31048901042.pdf

Torío, H. (2019). Teaching as Coaching: Experiences with a video-based Flipped Classroom combined with Project-based approach in technology and physics higher education. Journal of Technology and Science Education, 9(3), 404-419. https://doi.org/10.3926/jotse.554

Troncoso-Pantoja, C. A., Díaz-Aedo, F., Amaya-Placencia, J., \& Pincheira-Aguilera, S. (2019). Elaboración de videos didácticos: un espacio para el aprendizaje activo, FEM: Revista de la Fundación Educación Médica, 22(2), 91-92.

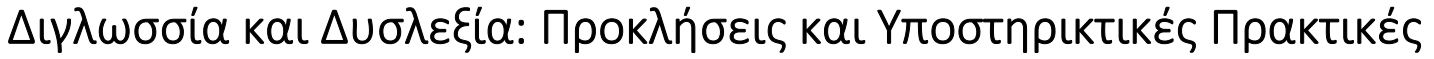

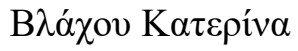

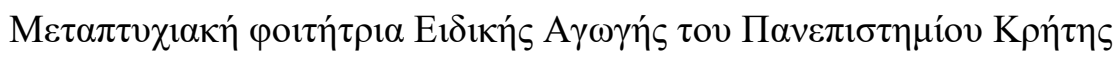

blachoukaterina@gmail.com

\section{Пєрі́ $\eta \psi \eta$}

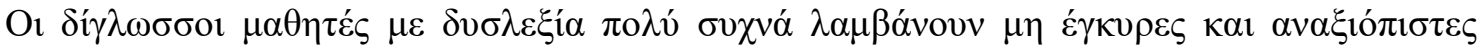

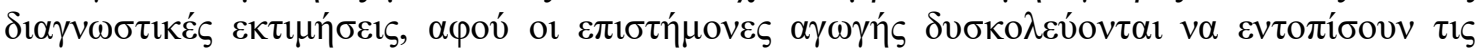

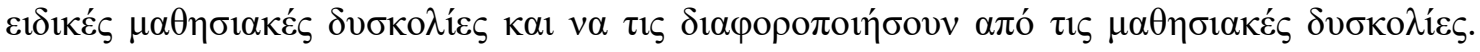

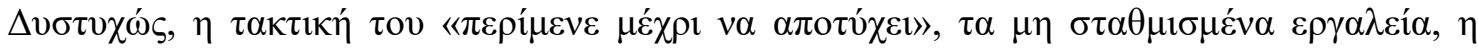

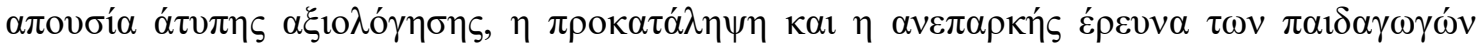

